ORNL/TM-2000/161

Chemical Technology Division

\title{
Assessment of Preferred Depleted Uranium Disposal Forms
}

\author{
A. G. Croff
}

J. R. Hightower

D. W. Lee*

G. E. Michaels ${ }^{\dagger}$

N. L. Ranek

J. R. Trabalka

\footnotetext{
*Energy Division, ORNL

${ }^{\dagger}$ Nuclear Technology Program Office, ORNL

*Argonne National Laboratory, Argonne, Illinois
}

Date Published: June 2000

\author{
Prepared by \\ OAK RIDGE NATIONAL LABORATORY \\ Oak Ridge, Tennessee 37831-6285 \\ managed by \\ UT-Battelle, LLC \\ for the \\ U.S. DEPARTMENT OF ENERGY \\ under contract DE-AC05-00OR22725
}




\section{CONTENTS}

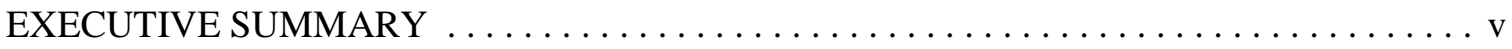

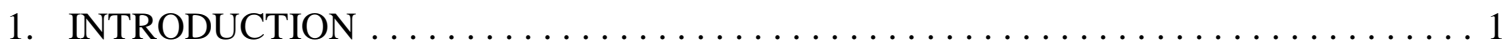

2. CHARACTERISTICS OF DEPLETED URANIUM PRODUCT FORMS $\ldots \ldots \ldots \ldots \ldots 1$

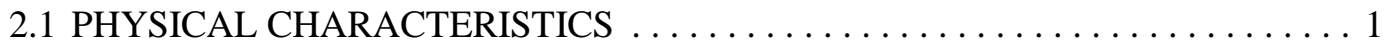

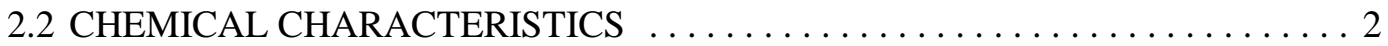

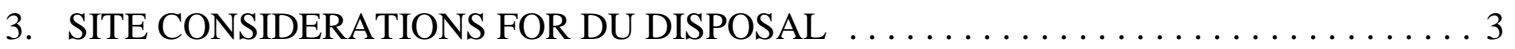

3.1 ACCEPTABILITY OF DU WASTE FORMS AT THE NTS $\ldots \ldots \ldots \ldots \ldots \ldots . . \ldots$

3.1.1 Radioactive Waste Acceptance Program Review to Initially Qualify

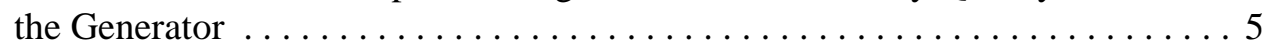

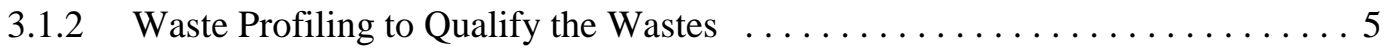

3.1.3 Audits, Assessments, and Surveillance ................... 7

3.1.4 Depleted Uranium Disposal Experience at the NTS . . . . . . . . . . . . 7

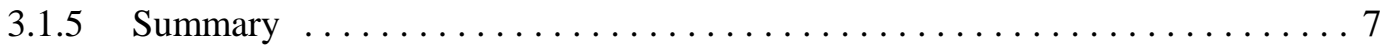

3.2 PRELIMINARY ASSESSMENT OF DU DISPOSAL AT OTHER SITES $\ldots \ldots \ldots 8$

3.3 COSTS OF PRODUCTION, TRANSPORTATION, AND DISPOSAL

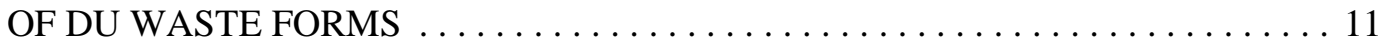

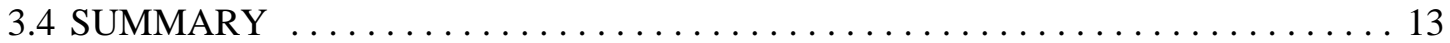

4. GENERAL CONSIDERATIONS REGARDING DISPOSAL OF DU AT NTS $\ldots \ldots \ldots 13$

4.1 DOE AND NRC RESPONSIBILITIES REGARDING DISPOSAL

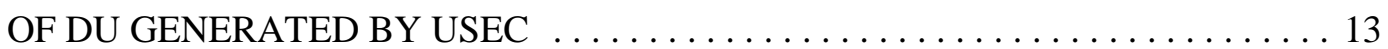

4.2 INSTITUTIONAL AND STAKEHOLDER ISSUES $\ldots \ldots \ldots \ldots \ldots \ldots \ldots \ldots \ldots$

4.3 IMPACTS OF TRACE IMPURITIES ON DISPOSAL AT THE NTS $\ldots \ldots \ldots \ldots 16$

4.4 UTILITY OF DU FORMS FOR POTENTIAL BENEFICIAL USES . . . . . . . . 17

4.5 NATIONAL ENVIRONMENTAL POLICY ACT $\ldots \ldots \ldots \ldots \ldots \ldots \ldots \ldots \ldots \ldots$

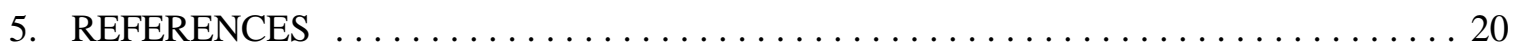




\section{EXECUTIVE SUMMARY}

The Department of Energy (DOE) is in the process of converting about 700,000 metric tons (MT) of depleted uranium hexafluoride $\left(\mathrm{DUF}_{6}\right)$ containing 475,000 MT of depleted uranium (DU) to a stable form more suitable for long-term storage or disposal. Potential conversion forms include the tetrafluoride $\left(\mathrm{DUF}_{4}\right)$, oxide $\left(\mathrm{DUO}_{2}\right.$ or $\left.\mathrm{DU}_{3} \mathrm{O}_{8}\right)$, or metal. If worthwhile beneficial uses cannot be found for the DU product form, it will be sent to an appropriate site for disposal. The DU products are considered to be low-level waste (LLW) under both DOE orders and Nuclear Regulatory Commission (NRC) regulations. The objective of this study was to assess the acceptability of the potential DU conversion products at potential LLW disposal sites to provide a basis for DOE decisions on the preferred DU product form and a path forward that will ensure reliable and efficient disposal.

This study begins with a brief review of the physical and chemical properties of the four DU product forms to provide a basis for subsequent analysis. Then, the potential acceptability of the DU product forms at various LLW disposal sites is evaluated, with emphasis on the Nevada Test Site (NTS). Next, the costs for producing, packaging, transporting, and disposing of each of the DU product forms are estimated and compared. Other considerations that could affect the acceptability of or preference for any of the DU conversion plant products for disposal were also evaluated. These included (1) the potential impacts of the United States Enrichment Corporation (USEC) origin of some of the tails on regulatory jurisdiction, (2) institutional and stakeholder issues, (3) the presence of trace impurities such as ${ }^{99} \mathrm{Tc}$ and transuranic elements, (4) the projected utility of each product form for beneficial use, and (5) National Environmental Policy Act (NEPA) considerations.

- On balance, the four potential forms of DU (DU metal, $\mathrm{DUF}_{4}, \mathrm{DUO}_{2}$, and $\mathrm{DU}_{3} \mathrm{O}_{8}$ ) considered in this study should be acceptable for near-surface disposal at sites such as the NTS and Envirocare. The NTS has disposed of DU metal, $\mathrm{DUF}_{4}, \mathrm{DUO}_{2}$, and $\mathrm{DU}_{3} \mathrm{O}_{8}$, albeit in much smaller quantities than those considered here. Although some characteristics (e.g., very fine particles, sorbed hydrogen fluoride (HF), and/or potential pyrophoricity) of each of the forms could limit the acceptability of DU for disposal, these characteristics reportedly can be controlled via proper technical specifications imposed on the DU product forms.

- The NTS is the preferred DU disposal site because of its unique geohydrologic and institutional setting. The NTS is one of two preferred regional LLW disposal sites recently identified by DOE and also has accommodating waste acceptance criteria (WAC) for all of the DU forms. Disposal of DU at Envirocare appears to be questionable, and current DOE policy would require justification for not using the NTS or another DOE LLW disposal site. Disposal of any DU product form at the other preferred regional LLW disposal site (Hanford) is less desirable because it has more restrictive WAC and less flexibility to accommodate the unique nature of DU. Waste disposal at other DOE LLW disposal sites is impractical because they are not designated as preferred regional sites, have limited capacity, and have much more restrictive WAC than the NTS because of site-specific conditions.

- Characteristics of the DU forms such as particle sizes and uranium densities, coupled with package size/weight limitations, preclude verbatim compliance with the Nevada Test Site Waste Acceptance Criteria (NTSWAC) for any of the forms. However, the NTSWAC are designed to be flexible so as to address generator needs provided they meet regulatory standards. Establishing DU-specific requirements that meet the NTSWAC while optimizing 
disposal efficiency is feasible, although there are significant uncertainties regarding the time and cost needed to accomplish this. Each DU form has a degree of uncertainty regarding acceptability, with the uncertainty decreasing in the following order: $\mathrm{DU}$ metal, $\mathrm{DUF}_{4}, \mathrm{DUO}_{2}$, and $\mathrm{DU}_{3} \mathrm{O}_{8}$.

- Institutional and stakeholder issues (e.g., avoiding certain transportation routes) are minimal, and those that exist appear to be resolvable.

- The total estimated cost of converting 700,000 $\mathrm{MT}_{\text {of }} \mathrm{DUF}_{6}$ and packaging, transporting, and disposing of it is lowest for $\mathrm{DUF}_{4}$, ranging from $\$ 730 \mathrm{M}$ to $1100 \mathrm{M}$. The costs for oxide forms are the next most economical and fall in the range of $\$ 1200 \mathrm{M}-\$ 1500 \mathrm{M}$. A DU metal form is the most expensive at $\sim \$ 2500 \mathrm{M}$.

- Of the four forms of DU, $\mathrm{DUO}_{2}$ has the most utility for beneficial uses, followed by the metal form. Neither $\mathrm{DU}_{3} \mathrm{O}_{8}$ nor $\mathrm{DUF}_{4}$ has any direct utility, and while both can be converted to either metal or other oxides, this is more readily accomplished via $\mathrm{DUF}_{4}$ using established processes.

- Trace contaminants should not be a significant issue because they are expected to be present at very low concentrations and can be characterized readily in the homogeneous conversion plant product(s).

- The presence of DU generated by USEC in the DOE inventory suggests no circumstances giving the NRC jurisdiction over disposal activities at the NTS regardless of the chemical form of the DU.

- The NRC has expressed concern about the viability of near-surface disposal of DU in some specific chemical forms and about near-surface disposal of large amounts of DU in any form. However, these concerns appear to be based on disposal scenarios involving humid sites, which have much greater limitations than the arid, controlled-access setting at the NTS.

- Additional NEPA actions may be needed if $\mathrm{DUF}_{4}$ were to be the conversion product or disposal form or if DU metal were to be the disposal form because these options were excluded in the $\mathrm{DUF}_{6}$ Record of Decision (ROD). It is also possible that additional sitespecific or programmatic NEPA actions will be needed to dispose of any form of DU because DU disposal was not included in the ROD.

- The requirements for resolution of current issues concerning disposal of DU product forms at the NTS should form part of the basis for preparing the request for proposal for sector conversion of DUF 6 . This suggests that the DOE Office of Nuclear Energy should immediately begin discussions with the DOE Nevada Operations Office to establish DUspecific requirements to meet the NTSWAC and obtain agreement on operational approaches for disposal at the NTS. These discussions should address the following aspects of DU product form disposal at the NTS:

$\mathrm{S}$ Alternative package specifications that minimize void space and cost.

S Alternative operational procedures that might allow heavier DU packages.

$\mathrm{S}$ Alternative disposal methods that would facilitate recovery of DU if a national need were to arise.

S Exploration of the potential for shipment and emplacement of DU product forms in bulk. 
S The need for a supplement to the NTS LLW disposal performance assessment prior to accepting DU for disposal.

S Means for resolution of potential stakeholder issues such as opposition to the Yucca Mountain repository project or the presence of trace impurities in the DU product.

Consideration should also be given to preparation of a technical background document designed to support resolution of uncertainties in the physical and chemical properties of the four potential DU disposal forms as input for the discussions described above. Emphasis should be placed on the less-familiar DU product forms (i.e., DU metal and DUF $_{4}$ ), but all four forms should be addressed. 


\section{INTRODUCTION}

The Department of Energy (DOE) is in the process of converting about 700,000 metric tons (MT) of depleted uranium hexafluoride $\left(\mathrm{DUF}_{6}\right.$ ) containing 475,000 MT of depleted uranium (DU) to a more stable form, which could include the tetrafluoride $\left(\mathrm{DUF}_{4}\right)$, oxide $\left(\mathrm{DUO}_{2}\right.$ or $\mathrm{DU}_{3} \mathrm{O}_{8}$ ), metal, or a combination of these forms. If worthwhile beneficial uses cannot be found for the converted DU product, it will be sent to an appropriate site for disposal. The DU products are considered to be low-level waste (LLW) under both DOE orders and Nuclear Regulatory Commission (NRC) regulations. The objective of this study was to assess the acceptability of the potential DU conversion products for disposal at likely LLW disposal sites to provide a basis for DOE decisions on the preferred form of the DU product and a path forward that will ensure a reliable and efficient disposal path.

\section{CHARACTERISTICS OF DEPLETED URANIUM PRODUCT FORMS}

The differing characteristics of various potential DU conversion products can have a significant impact on the acceptability of these forms for disposal. The physical and chemical characteristics of the potential DU conversion products that are relevant to the packaging, transportation, and disposal of each DU product form are reviewed briefly in the following sections.

\subsection{PHYSICAL CHARACTERISTICS}

Table 1 presents physical properties of potential conversion products. The bulk densities for the production forms of DU compounds are much lower than the theoretical densities, which are maximum values obtainable only for crystalline forms or for cast/sintered monoliths. Bulk densities are highly variable for some forms because of specific details of the conversion process such as the mix of particle or aggregate sizes, the degree of settling that occurs or is caused to occur, and whether products are sintered to increase density. With suitable prior specification, densities near the upper end of indicated ranges appear to be achievable. Achieving a higher density is a necessary prerequisite to lowering the volume of the DU conversion products other than metal and, thus, potentially reducing the cost of packaging, transportation, and disposal (see Sect. 3.3).

Table 1. Physical properties and projected quantities of potential DUF 6 conversion products

\begin{tabular}{cccccc}
\hline & & \multirow{2}{*}{$\begin{array}{c}\text { Bulk } \\
\text { density }\end{array}$} & & \multicolumn{2}{c}{ Volume $\left(\times 10^{3} \mathrm{~m}^{3}\right)$} \\
\cline { 5 - 6 } & Mol.wt. & $\left(\mathrm{MT} / \mathrm{m}^{3}\right)$ & $\left(\times 10^{3} \mathrm{MT}\right)$ & Median & Range \\
\hline DU metal & 238 & 19 & 473 & 24.9 & \\
$\mathrm{DUF}_{4}$ & 314 & $2.0-4.5$ & 624 & 192 & $139-312$ \\
$\mathrm{DUO}_{2}$ & 270 & $2.0-5.9$ & 537 & 153 & $91-268$ \\
$\mathrm{DU}_{3} \mathrm{O}_{8}$ & 842 & $1.5-4.0$ & 558 & 203 & $140-372$ \\
\hline
\end{tabular}

${ }^{a}$ Based on data obtained from Duerksen et al. (2000) and Dubrin et al. (1997).

${ }^{b}$ Based on 700,000 MT of DUF . 


\subsection{CHEMICAL CHARACTERISTICS}

The most important chemical characteristics of the various potential DU products are their solubility in water (high solubility enhances transport by water) and their degradation via reactions with water, which are summarized in Table 2.

Table 2. Chemical properties of uranium and its compounds under ambient conditions

\begin{tabular}{|c|c|c|}
\hline Compound & Solubility in water & Chemical reactions \\
\hline DU metal & Insoluble & $\begin{array}{l}\text { - Reacts slowly with moisture to form oxides in the } \\
\text { presence of oxygen; condensed moisture promotes } \\
\text { generation of } \mathrm{H}_{2} \\
\text { - Reactions may form pyrophoric surface in absence } \\
\text { of } \mathrm{O}_{2}\end{array}$ \\
\hline $\mathrm{DUF}_{4}$ & Very slightly soluble & $\begin{array}{l}\text { Reacts slowly with moisture to form } \mathrm{DUO}_{2} \text { and } \\
\text { hydrogen fluoride (HF) and eventually other } \\
\text { oxides and minerals }\end{array}$ \\
\hline $\mathrm{DUO}_{2}$ & Insoluble & $\begin{array}{l}\text { - Powder only can be pyrophoric in air } \\
\text { - Reacts very slowly with oxygenated groundwater } \\
\text { to yield more stable oxides and minerals }\end{array}$ \\
\hline $\mathrm{DU}_{3} \mathrm{O}_{8}$ & Insoluble & $\begin{array}{l}\text { - Reacts very slowly with oxygenated water to yield } \\
\text { more stable uranium minerals } \\
\text { - Product tends to be a fine particulate or powder }\end{array}$ \\
\hline
\end{tabular}

Sources: Biwer et al. 2000; DOE 1999a; Duerksen et al. 2000.

Metal. Depleted uranium metal reacts slowly with moisture under ambient conditions to produce DU oxides and hydrogen. The oxide layer normally spalls, allowing the reaction to continue with a fresh metal surface. Reaction rates in air are slow, ranging from $2 \times 10^{-5}$ to $4 \times 10^{-4} \mathrm{mg} / \mathrm{cm}^{2}$. Much higher rates are observed under saturated anaerobic conditions. No detectable hydrogen is formed in the presence of oxygen except under circumstances that permit condensation of water on the metal surface and limit the transport of oxygen from the gas phase to the metal surface. There are a number of anecdotal reports of bulk uranium ignition that have been attributed to the formation of uranium hydride layers under saturated anaerobic conditions produced in storage containers [e.g., see Biwer et al. (2000)]. However, a recent evaluation of DU metal ignition potential concludes that hydriding is not required to explain such events (Epstein et al. 1996). In addition, while the conditions that had been thought to result in hydriding could occur in both disposal and storage environments if a water layer sufficient to inhibit access of oxygen to the uranium surface (Biwer et al. 2000; Duerksen et al. 2000) is present, such conditions are not likely to be significant in arid climates and unsaturated soils. Thus, it does not appear that hydriding or hydrogen generation should be significant problems under disposal conditions expected at arid sites such as the Nevada Test Site (NTS).

Tetrafluoride. Depleted uranium tetrafluoride is nonvolatile, nonhygroscopic, and only very slightly soluble in water ( $40 \mathrm{ppm}$ at room temperature) (Katz, Seaborg, and Morss 1986). However, evolution of fluoride ions, believed to result from chemisorbed HF, has been observed 
in stored $\mathrm{UF}_{4}$. However, chemisorbed $\mathrm{HF}$ can be removed during production by heating the $\mathrm{DUF}_{4}$ product. In addition, $\mathrm{DUF}_{4}$ reacts very slowly with moisture at ambient temperatures to form $\mathrm{DUO}_{2}$ and $\mathrm{HF}$ (Duerksen et al. 2000). If not removed, the HF will enhance the corrosion rate of the packages.

Dioxide. Finely divided $\mathrm{DUO}_{2}$ (i.e., powder) exhibits pyrophoric behavior. However, aggregates such as granules, pellets, and monoliths do not exhibit such behavior (Biwer et al. 2000; Duerksen et al. 2000). Depleted uranium dioxide is very slowly oxidized to other oxides and then to stable uranium-bearing minerals by oxygenated groundwater. Such transformations are the subject of intense study in the context of the proposed repository at Yucca Mountain, Nevada, located at the western edge of the NTS.

Triuranium Octaoxide. The chemical behavior of $\mathrm{DU}_{3} \mathrm{O}_{8}$ is very similar to that of $\mathrm{DUO}_{2}$ except that $\mathrm{DU}_{3} \mathrm{O}_{8}$ powder does not exhibit pyrophoric behavior. However, production of $\mathrm{DU}_{3} \mathrm{O}_{8}$ tends to yield significant amounts of very fine particles, which may not be acceptable for disposal without further treatment or packaging.

Summary Observations. Despite the very different chemical forms of the DU conversion products considered, all have essentially similar characteristics relevant to waste disposal. All have low to very low solubility in water, and all react very slowly with water to yield degradation products that are typically more stable and have a lower density (and hence greater volume) than the parent species. None of the reactions occur at a rate which would make the materials "reactive" as the term is generally interpreted in the context of managing wastes. One potential exception involves hydrogen production or pyrophoricity of hydride layers on DU metal. This concern is unlikely to be significant in an arid disposal setting such as the NTS. A second potential exception is the pyrophoricity of finely divided $\mathrm{DUO}_{2}$ powder, which can be eliminated by specification of a larger aggregate as the conversion product.

\section{SITE CONSIDERATIONS FOR DU DISPOSAL}

Disposal of DU as a LLW requires that the waste form and package meet the Waste Acceptance Criteria (WAC) for the disposal facility. These requirements are conceptually the same for all disposal facilities but vary in detail because of differing site characteristics and disposal operations. The process for demonstrating compliance with waste acceptance requirements can be time-consuming and costly unless the requirements are coordinated with the selection of the waste form and package. This section first examines the waste acceptance requirements at the NTS and other disposal sites that are applicable to the disposal of DUF $_{6}$ conversion products. Then, costs for producing, transporting, and disposing of DU at the NTS are estimated and compared.

\subsection{ACCEPTABILITY OF DU WASTE FORMS AT THE NTS}

The NTS is a vast area of land north of Las Vegas, Nevada, within the Nellis Air Force Range. The NTS is a secure site with an area of $3500 \mathrm{~km}^{2}$, which is large enough to include all of the District of Columbia and all of its adjoining cities and communities (Fig. 1). The average annual 
rainfall at the NTS ranges from 10 to $15 \mathrm{~cm}$. However, the annual evaporation is approximately 14 times greater than the amount of rainfall.

The NTS has two low-level radioactive waste disposal facilities. The Area 3 disposal facility is located in Yucca Flat and uses subsidence craters from past underground nuclear tests as disposal

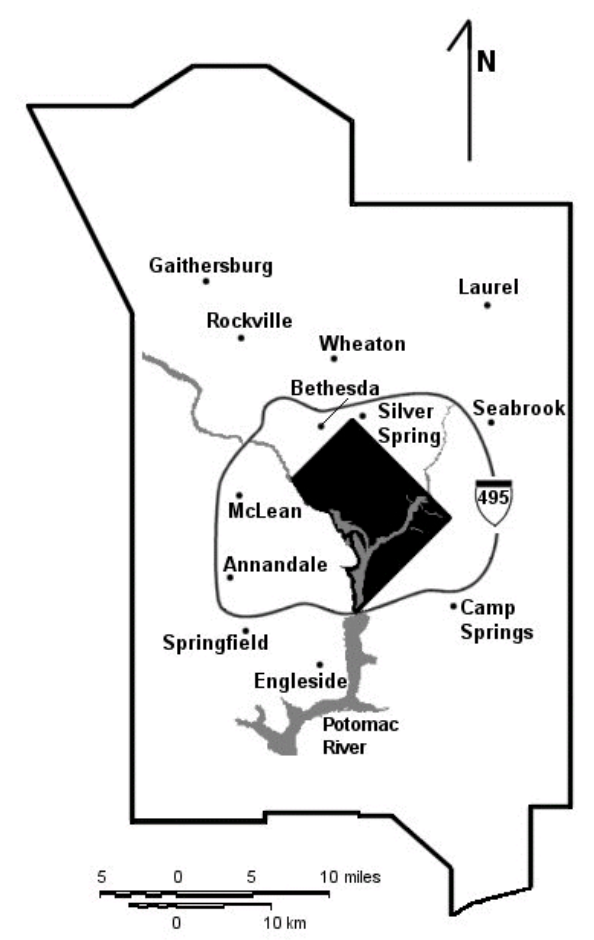

Fig. 1. Superposition of the NTS boundary and the Washington, D.C., metropolitan area to scale. cells. The depth to the groundwater in Area 3 is $500 \mathrm{~m}$. This facility accepts uncontainerized wastes and large bulk containers of waste. The current and planned capacity in Area 3 is $566,336 \mathrm{~m}^{3}$, of waste with an additional future capacity of $3,398,016 \mathrm{~m}^{3}$, for a total available capacity of nearly 4 million cubic meters. The Area 5 disposal facility is located in Frenchman Flat and uses shallow land burial technology for disposal. The depth to the groundwater in Area 5 is $235 \mathrm{~m}$. Area 5 accepts containerized waste such as boxes and drums. The current and planned capacity in Area 5 is $169,900 \mathrm{~m}^{3}$ of waste with an additional future capacity of 2,973,264 $\mathrm{m}^{3}$, for a total available capacity of over 3 million cubic meters. Consequently, the projected capacity required for DU disposal (less than $400,000 \mathrm{~m}^{3}$; see Table 1) is easily accommodated at the NTS.

Wastes accepted for disposal in Areas 3 and 5 must meet the Nevada Test Site Waste Acceptance Criteria (NTSWAC) (DOE/NV 1999). These criteria require separate processes for approval of generators and waste streams by the DOE Nevada Operations Office (DOE/NV). The approval process is described in detail in the NTSWAC. The process includes the documentation requirements for waste generator and the Radioactive Waste Acceptance Program (RWAP) Review performed by DOE/NV. The purpose of the program review is to ensure that the provisions of the NTSWAC can and will be met by the generator. The approval process consists of the following:

- $\quad$ The initial waste generator approval review-This review examines the generator's proposed implementation of the NTSWAC.

- $\quad$ The waste profile approval process-The waste profile summarizes the characterization and the NTSWAC compliance of a waste stream. The waste profile must be prepared by the generator and approved by DOE/NV prior to shipment of waste to the NTS for disposal. The review process supporting the DOE/NV approval decision includes examination of the profile of each waste stream proposed for disposal by the NTS Waste Acceptance Review Panel, which may (1) require the development of additional information, (2) recommend the waste stream for approval, and/or (3) recommend surveillance of the waste stream at the generator's site.

- Facility evaluations-These evaluations include a triennial audit of compliance with the NTSWAC, an annual assessment of a generator's program, and surveillance when appropriate. 
RWAP personnel recommend approval to DOE/NV once a generator has demonstrated satisfactory implementation of the NTSWAC. Approval of waste streams or waste generators may be suspended if the generator's documentation or wastes do not meet the NTSWAC requirements.

\subsubsection{Radioactive Waste Acceptance Program Review to Initially Qualify the Generator}

An audit of a new generator is performed by DOE/NV as part of the RWAP. This audit is a thorough examination and evaluation of the generator program and documentation for compliance with the NTSWAC. The audit is intended to ensure the generator's waste certification, characterization, packaging, and shipping program are complete and fully implement the NTSWAC. The associated documentation and waste profiles are also included in this initial audit.

\subsubsection{Waste Profiling to Qualify the Wastes}

Wastes accepted for disposal at the NTS must be radioactive and meet the criteria included in the NTSWAC. Of the 15 general waste form criteria and the 10 waste package criteria, only a few are of special concern to the disposal of DU and are discussed below. The NTSWAC are designed to be flexible, and compliance with these criteria is achieved by DOE/NV working with generators. As a result, alternative methods for meeting the NTS waste form criteria may be incorporated into the waste acceptance program for a specific generator or waste stream profile.

Resource Conservation and Recovery Act (RCRA). Waste accepted for disposal at the NTS cannot exhibit the characteristics of, or be listed as, hazardous wastes according to federal regulations implementing the RCRA (i.e., 40 CFR Part 261), state of Nevada regulations, or hazardous waste regulations of the state in which the waste was generated. State of Nevada regulations require that waste regulated as hazardous in the state in which it was generated must be regulated as hazardous when brought into the state of Nevada. None of the potential DU conversion product forms appear to meet the federal definition of hazardous waste, with the possible exception of untreated $\mathrm{DUO}_{2}$ powders, which have a pyrophoric nature. Furthermore, the states where DU conversion is most likely to occur (i.e., Kentucky and Ohio) do not designate the potential DU conversion product forms as hazardous waste under state regulations.

Particulates. The NTSWAC require fine particulate wastes to be immobilized such that the waste package contains no more than $1 \mathrm{wt} \%$ of less than $10-\mu \mathrm{m}$-diam particles or $15 \mathrm{wt} \%$ of less than $200-\mu \mathrm{m}$-diam particles. Aggregated DU product forms should not require any additional treatment to meet this requirement. However, the ability to produce $\mathrm{DU}_{3} \mathrm{O}_{8}$ in the form of a sufficiently large aggregate is uncertain. If the requirements for limitation of fine particulate content cannot be met, additional costs for packaging (e.g., overpacks, sealed liners) or stabilization in a suitable matrix (e.g., grout) would result. The determination of the need to immobilize the waste form would be addressed in the waste program and waste stream profile reviews prior to approval and shipment of the wastes.

Stability. Wastes shipped to the NTS for disposal must be stable. The wastes must not exhibit unacceptable reactions with the packaging during storage, shipping, handling, or disposal. Chemical stability and reactivity must be demonstrated to ensure that no reactions occur and no 
significant quantities of harmful gases, vapors, or liquids are generated. The required demonstration and determination of the nonreactive nature of the wastes are included in the waste program and waste stream profile reviews that are conducted prior to approval of the wastes for shipment to the NTS. For slightly reactive waste forms such as $\mathrm{DUF}_{4}, \mathrm{UO}_{2}$ powder, or uranium metal, this requirement could result in additional packaging costs or lead to extended reviews of the waste program or waste stream profile.

Pyrophoric. Wastes accepted for disposal at the NTS must not be pyrophoric as defined in the NTSWAC. Any material considered to be pyrophoric is required to be treated, prepared, or packaged to be nonflammable. For uranium metal or $\mathrm{DUO}_{2}$ powder, this requirement could lead to additional packaging costs or extended reviews of the waste program or waste stream profile. The need for additional treatment, preparation, or packaging of wastes would be addressed as part of the waste program and waste stream profile reviews prior to approval or shipment of the waste.

Package Size, Weight, DU Activity, and Void Limits. The NTSWAC for disposal of containerized materials at Area 5 contains four interrelated specifications that affect the design and number of packages containing DU product forms: package size, package weight, and the total DU activity per unit volume of a package (i.e., curies per cubic meter).

- While a number of package sizes have been specified for use at the NTS because of the high density of DU product forms, only two are considered here for disposal of DU. The primary container considered is a $0.21-\mathrm{m}^{3}(55-\mathrm{gal})$ drum. In addition, previous studies have also assumed that a nonstandard $0.31-\mathrm{m}^{3}\left(11-\mathrm{ft}^{3}\right)$ metal box would be most suitable for high-density DU metal.

- $\quad$ The NTSWAC have provisions requiring that excessive void spaces in waste packages be minimized. The purpose of this provision is to reduce subsequent subsidence and infiltration of precipitation into the waste.

- The weight of a loaded drum and metal box is limited to 0.54 and $4.08 \mathrm{MT}$, respectively. This is based on limits in the ability of forklifts to emplace the waste using present operating practices at the NTS. A drum or full-size box could only be partially filled with DU products having a density greater than $\sim 2.5 \mathrm{MT} \mathrm{DU} / \mathrm{m}^{3}$. The voids resulting from the inefficiency in filling the container would not likely be acceptable under the NTSWAC and thus would have to be addressed as a part of the waste generator and waste profile approval process.

- The DU concentration in any of the packages (i.e., the activity of the DU in the package divided by the volume of the waste in the package) is limited to $1.59 \mathrm{Ci} / \mathrm{m}^{3}$. DU metal having a density of $19 \mathrm{~g} / \mathrm{cm}^{3}$ has an activity of $0.37 \mathrm{Ci} / \mathrm{MT}$. As a result, any DU product form with a density greater than $\sim 4.3 \mathrm{MT} \mathrm{DU} / \mathrm{m}^{3}$ would result in the package being only partially filled, a condition that is not acceptable under the NTSWAC and which would have to be addressed as a part of the waste generator and waste profile approval process.

In the case of the high-density DU product forms, partial filling of packages because of limits on weight and uranium activity could result in voids that are not acceptable under the NTSWAC. This inconsistency can be resolved by specifying a smaller package or alternative waste operations, but this remains the topic of future discussions. As with the other issues identified here, this issue would be addressed as part of the RWAP process of approving the waste generator and the waste stream profile. 
Characterization. The characterization of the waste materials is required by the NTSWAC. Waste characterization may be performed by process knowledge, sampling and analysis, or a combination of both. For DU disposal at the NTS, the relatively homogeneous nature of the DUF $_{6}$ conversion product simplifies the waste characterization requirements. Some uncertainty in waste characterization is associated with the potential presence of trace impurities such as transuranic radionuclides, thorium, and ${ }^{99} \mathrm{Tc}$. This is addressed in more detail in Sect. 4.3.

Performance Assessment (PA). While the capacity for disposal is available at the NTS, the existing PA for the NTS, which is required by DOE O 435.1, does not consider a DU waste stream volume as large as that which would result from DUF $_{6}$ conversion. Consequently, an addendum or supplement to the PA, which could introduce additional requirements for the disposal of DU at the NTS, may be needed. Based on the contents of the existing PA, larger amounts of any of the DU product forms should be acceptable with the addition of a thicker cap to impede radon emanation.

Storage vs Disposal. The NTS will accept only DUF ${ }_{6}$ conversion products for disposal. The NTS is not permitted to store wastes or other materials from other DOE sites. Consequently, a formal concept of retrievable storage of $\mathrm{DUF}_{6}$ conversion products is not acceptable. The disposal of DU in a dedicated trench at Area 5 is possible and could be considered by DOE/NV. Such a disposal concept might lead to reduced overall costs for the disposal of $\mathrm{DUF}_{6}$ conversion products while enabling the recovery of disposed DU materials if a national need arose.

\subsubsection{Audits, Assessments, and Surveillance}

After initial qualification of the generator and the waste stream(s), audits, assessments, and surveillance are performed by DOE/NV for all waste generators who dispose of wastes at the NTS. Audits of generators are conducted every 3 years to verify by examination and evaluation of evidence that (1) waste generator documents contain the necessary elements to meet the NTSWAC and (2) all elements of the program have been properly implemented. The scope includes waste characterization, quality assurance, and traceability of waste certification elements. Annual assessments are performed to address program changes, operational concerns, and internal assessments. An annual assessment could result in on-site surveillance of waste generation at the discretion of DOE/NV to verify corrective actions, review new waste streams or program elements, resolve discrepancies, and/or ensure compliance with specific requirements of the NTSWAC.

\subsubsection{Depleted Uranium Disposal Experience at the NTS}

All forms of DU considered in this report have been disposed of directly at the NTS (Thomas 1999; Sattler 2000). The Fernald Plant, in particular, has sent sizeable quantities of these DU forms for disposal at the NTS. Table 3 lists quantities and descriptions of DU wastes from Fernald that have been disposed of at the NTS. This information is not a complete listing of such wastes from Fernald disposed of at the NTS because the data provided for this study were based on a partial review of available records at Fernald. The waste profile describes containers to be used which include $0.21-\mathrm{m}^{3}$ drums, $0.32-\mathrm{m}^{3}$ drums, and $3.2-\mathrm{m}^{3}$ boxes. Fernald routinely ships packages weighing more than the nominal 4.08-MT limit in the WAC after obtaining prior 
approval from the NTS. Although this experience indicates that disposal of DU forms is possible at the NTS, it does not imply that the the large amounts of converted DU product form(s) envisioned in the $\mathrm{DUF}_{6}$ Management Program would be a priori acceptable for disposal at the NTS.

\subsubsection{Summary}

The proposed DU waste forms do not have characteristics that prohibit disposal at the NTS. However, there are several issues to be resolved that could lead to delays and increased costs for the treatment and packaging of the DUF ${ }_{6}$ conversion product. The resolution of these issues is an inherent part of developing the RWAP. Based on the preliminary information that is available, the disposal of DUF $_{6}$ conversion material at the NTS should be approved once the RWAP process is completed and all issues have been resolved. The time and cost required for resolving the issues identified above are unpredictable, as are any additional costs for the disposal of DU that result from actions required to resolve the issues.

Table 3. Depleted uranium forms from Fernald disposed at the NTS

\begin{tabular}{|c|c|c|c|c|}
\hline DU form & Description & Compounds included & $\begin{array}{c}\text { Waste quantity } \\
(\mathrm{kg})\end{array}$ & $\begin{array}{c}\text { Uranium weight } \\
(\mathrm{kg})\end{array}$ \\
\hline $\mathrm{U}_{3} \mathrm{O}_{8}$ & $\begin{array}{l}\text { Residues, dust } \\
\text { collector, furnace, } \\
\text { oxidized } \mathrm{U}_{3} \mathrm{O}_{8}\end{array}$ & $\mathrm{U}_{3} \mathrm{O}_{8}$ & 578,000 & 418,000 \\
\hline $\mathrm{UF}_{4}$ & $\begin{array}{l}\text { Salts, residues, dust } \\
\text { collector }\end{array}$ & $\mathrm{UF}_{4}, \mathrm{U}_{3} \mathrm{O}_{8}$ & $1,870,000$ & 800,000 \\
\hline $\mathrm{UO}_{3}$ & Rejects & $\mathrm{UO}_{3}$ & $880^{a}$ & 723 \\
\hline U metal & $\begin{array}{l}\text { Metal, ingot, residue, } \\
\text { slag, salts }\end{array}$ & $\mathrm{U}$ metal, $\mathrm{U}_{3} \mathrm{O}_{8}, \mathrm{UF}_{4}$ & $1,120,000$ & 666,000 \\
\hline
\end{tabular}

${ }^{a}$ The Non-HEU Uranium Trade Study (Sink 1999), performed under the auspices of the Nuclear Material Integration activities, reports $25 \mathrm{MT}$ of depleted $\mathrm{UO}_{3}$ shipped from Fernald to NTS, which indicates that data in Table 3 may be incomplete.

\subsection{PRELIMINARY ASSESSMENT OF DU DISPOSAL AT OTHER SITES}

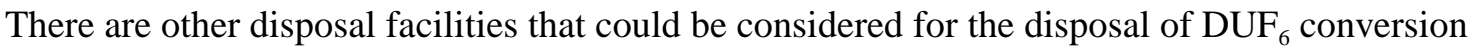
products. The most viable alternative in the DOE complex is the Hanford site, and in the commercial sector, Envirocare of Utah, Inc. Other alternatives are available in the DOE complex. This section assesses these alternatives and examines the DOE policy for the use of non-DOE facilities for the disposal of waste and the constraints on the use of non-DOE facilities in DOE O 435.1. This assessment should be considered preliminary because time did not permit site visits or direct discussions. Additionally, comments by the NRC on the disposal of DU are discussed.

Hanford. Disposal of LLW from other DOE sites at the Hanford site is controlled by the Hanford WAC in a manner similar to the NTS. Because of limitations on the concentration of uranium in waste materials that are derived from the performance assessments for the Hanford 
200 East and 200 West disposal facilities, Hanford is significantly less attractive than the NTS for the disposal of DU. These limitations on uranium concentrations in waste would preclude the disposal of DU that has not been consolidated with a matrix such as grout. For example, the allowable uranium concentration for disposal of unconsolidated DU is over two orders of magnitude lower than that in any DU conversion product. Consolidated DU has higher disposal concentration limits that are in the range of the uranium concentrations in $\mathrm{DUF}_{4}$ and the oxides. However, uranium metal clearly exceeds the concentration allowable at Hanford. Although the dilution provided by grout consolidation could permit the disposal of nonmetal DU conversion products at Hanford, the additional costs of treatment would provide a significant deterrent to the use of Hanford as an alternative disposal site.

Other DOE Sites. Other DOE sites with LLW disposal operations are Los Alamos, Idaho, Savannah River, and Oak Ridge. None of these sites has the capacity to accept the disposal volume to be generated from $\mathrm{DUF}_{6}$ conversion or has WAC that allow for disposal of untreated DU conversion products. The concentration limits for the disposal of uranium at other DOE sites are less than the concentrations of uranium in the DU conversion products by an order of magnitude or more. In addition, as part of the process leading to a Record of Decision (ROD) associated with the Waste Management Programmatic Environmental Impact Statement, DOE has announced Preferred Alternatives for the Disposal of Low-Level and Mixed Low-Level Wastes (Federal Register 1999). DOE prefers regional disposal of LLW at Hanford and the NTS, while continuing disposal operations at existing sites to the extent practicable.

Envirocare. Disposal of DU at Envirocare of Utah, Inc., as LLW is not specifically addressed by its WAC, but the following WAC, provisions would require further attention:

- $\quad$ The DU activity concentration must be less than $370,000 \mathrm{pCi} / \mathrm{g}$, which is equivalent to DU with an assay of $0.2 \%{ }^{235} \mathrm{U}$ and an activity concentration of ${ }^{234} \mathrm{U}$ less than natural. This criterion suggests that determining the acceptability of DUF $_{6}$ conversion materials as LLW at Envirocare would require additional investigation.

- Disposal of $\mathrm{DUF}_{6}$ conversion material as $11 \mathrm{e}(2)$ by-product material is limited by a waste acceptance criterion of $4000 \mathrm{pCi} / \mathrm{g}$ for natural uranium or for any radionuclide in the ${ }^{226} \mathrm{Ra}$ decay series. This concentration is two orders of magnitude less than the concentration that would be expected to be present in any $\mathrm{DUF}_{6}$ conversion material.

- Special Nuclear Material (SNM) quantity limits have been imposed by the NRC on Envirocare of Utah (NRC 1999). Under these limits, Envirocare of Utah can accept waste containers with uranium enrichments less than $10 \%$ and a maximum of $20 \% \mathrm{MgO}$ that have a maximum ${ }^{235} \mathrm{U}$ concentration of $1900 \mathrm{pCi} / \mathrm{g}$. With assays of ${ }^{235} \mathrm{U}$ in DU conversion products ranging from less than $0.2 \%$ to natural, the concentrations of ${ }^{235} \mathrm{U}$ in DU conversion products would range from 4300 to $15,000 \mathrm{pCi} / \mathrm{g}$, clearly exceeding the SNM limit at Envirocare.

In summary, the current WAC suggest that the acceptability of DUF $_{6}$ conversion material for disposal at Envirocare of Utah is questionable. Further investigation is required before a definitive determination can be made.

An institutional constraint to disposal of DOE-generated wastes at non-DOE (commercial) facilities such as Envirocare is imposed by DOE policy (DOE 1999b) and DOE O 435.1. An exemption approved by the Field Element Manager of the generator site is required by DOE $\mathrm{O}$ 
435.1 before wastes can be disposed of at commercial facilities. The approval of such an exemption is subject to several requirements that basically mandate the use of DOE facilities unless otherwise justified. Because the NTS is a viable site for the disposal of DUF $_{6}$ conversion products, the use of commercial disposal facilities would be difficult to justify under the existing policy and DOE O 435.1.

NRC Views. In the matter of the Louisiana Energy Services, L.P. (LES), application for an NRC license to construct and operate a uranium enrichment plant in Claiborne Parish, Louisiana (Claiborne Enrichment Center), the NRC staff analyzed land disposal of DU. In 1992, the NRC staff expressed a preference for $\mathrm{U}_{3} \mathrm{O}_{8}$ as the chemical form for final disposition and advised LES that disposal as $\mathrm{DUF}_{4}$ in a licensed 10 CFR Part 61 shallow land disposal facility located in a humid environmental setting would not be acceptable "because the physicochemical, long-term stability [of $\mathrm{DUF}_{4}$ ] is incompatible with final disposal under 10 CFR Part 61." In the Claiborne Enrichment Center Final Environmental Impact Statement (EIS), the NRC staff again recommended against land disposal of $\mathrm{DUF}_{4}$, stating that its reaction with water could produce quantities of $\mathrm{HF}$ that could compromise the integrity of a disposal facility and significantly disturb the environment (NRC 1994). The Final Claiborne Enrichment Center EIS also concluded that near-surface disposal of $\mathrm{DU}_{3} \mathrm{O}_{8}$ in a humid environmental setting would not comply with 10 CFR Part 61 (NRC 1992) performance objectives and suggested that deep disposal of some type might be necessary (NRC 1994, Appendix A). In 1995, during the scoping process for DOE's Programmatic Environmental Impact Statement (PEIS) (DOE 1999a) concerning long-term management of $\mathrm{DUF}_{6}$, the NRC staff repeated its opinion that $\mathrm{DU}_{3} \mathrm{O}_{8}$ is a likely chemical form for DU disposal. However, they also advised DOE that although $\mathrm{DU}_{3} \mathrm{O}_{8}$ could be disposed of in limited quantities in conventional near-surface disposal facilities, large quantities (such as would be derived from the nation's enrichment tailings inventory) suggest the possible need for a unique disposal facility, such as a mined cavity or an exhausted uranium mine (NRC 1995).

The NRC staff's views concerning the viability of DU disposal as $\mathrm{DUF}_{4}$ appear to have been based primarily on an analysis of a hypothetical near-surface disposal facility having characteristics typical of a humid southeastern site (Kozak 1992). In particular, this analysis considers intruder scenarios and dissolution and transport by groundwater that are not as credible at the arid NTS, where future intruder access is likely to be precluded by institutional control and groundwater is found only at significant depths with no recharge from the surface in areas where LLW disposal occurs.

Regarding disposal of DU in metal form, the NRC staff expressed a preference for uranium oxides over metal in comments on the PEIS concerning long-term management of $\mathrm{DUF}_{6}$ (DOE 1999a). This preference may be based on the potential oxidation or hydriding of DU metal in the presence of water, and the resultant potential for radiological and environmental consequences.

The NRC's concerns about $\mathrm{DUF}_{4}$ and DU metal as disposal forms are certainly appropriate for humid sites, such as may have been contemplated for the LES facility in Louisiana. However, such concerns do not appear to be as applicable to a controlled, arid site such as the NTS, where (1) the average annual potential evaporation is 14 times greater than average annual rainfall and (2) the presence of water in the near surface is expected to be ephemeral. Current measures to prevent intruder access are being considered by DOE for long-term stewardship of the NTS. The only significant performance issue is expected to be radon release, and this can be controlled 
using an impermeable cap such as those used at uranium mill tailing sites. The existing documentation and performance analyses supporting LLW disposal at the NTS suggest that the potential impacts to the public from DU disposal at the NTS LLW disposal facilities would be insignificant as long as requirements based on the NTSWAC are met. However, simply by the fact of their existence and the authority of the NRC, the views of the NRC staff will probably need to be addressed as part of the process of demonstrating the acceptability of DU for disposal at the NTS.

\subsection{COSTS OF PRODUCTION, TRANSPORTATION, AND DISPOSAL OF DU WASTE FORMS}

This section will focus on the NTS because of its attractiveness for disposal of DU product forms as compared with the other disposal alternatives, as described in Sects. 3.1 and 3.2.

Impact of Weight and DU Activity Limitations. The simultaneous limits on package size, weight, and uranium activity described in Sect. 3.1 have an important impact on the cost of packaging, shipping, and disposing of DU because of the relatively high density of the DU product forms. Specifically, the number of containers required for disposal of the DU product forms is increased by weight and DU concentration limitations on the standard containers acceptable under the NTSWAC. The number of packages and amount of DU per package based on the bulk density ranges given in Table 1 and not exceeding the more limiting of the existing weight and DU activity provisions in the NTSWAC are given in Table 4.

Table 4. Container requirements for potential DU product forms

\begin{tabular}{lcccc}
\hline DU product & Container & \% of container filled & $\begin{array}{c}\text { DU product per } \\
\text { container, MT }\end{array}$ & Number of containers \\
\hline DU metal & $0.31-\mathrm{m}^{3}$ box & $65^{a}$ & 3.86 & 123,000 \\
$\mathrm{DUF}_{4}$ & $0.21-\mathrm{m}^{3}$ drum & $100-55$ & 0.53 & $1,000,000-1,600,000$ \\
$\mathrm{DUO}_{3}$ & $0.21-\mathrm{m}^{3}$ drum & $100-42^{a}$ & 0.53 & $850,000-1,400,000$ \\
$\mathrm{DU}_{3} \mathrm{O}_{8}$ & $0.21-\mathrm{m}^{3}$ drum & $100-62$ & 0.53 & $1,050,000-1,900,000$ \\
\hline
\end{tabular}

${ }^{a}$ Exceeds allowable DU activity concentration limit by $2 \%$.

As noted in Sect. 3.1, the presence of excess voids in containers can be a concern with respect to disposal at the NTS.

Conversion Cost. Cost estimates for conversion of $\mathrm{DUF}_{6}$ to the forms identified in Tables 1 and 2 were based primarily on simplified (and unescalated) life cycle costs for conversion of 448,000 MT of DUF 6 to either DU metal or $\mathrm{DU}_{3} \mathrm{O}_{8}$ developed by Reid (1999). These cost data were linearly extrapolated to account for the increase in the quantities of products resulting from conversion of 700,000 MT of $\mathrm{DUF}_{6}$.

The cost for converting $\mathrm{DUF}_{6}$ to $\mathrm{DUF}_{4}$ had to be estimated separately because the $\mathrm{DUF}_{4}$ product form was not considered in previous studies. The approach used data from Lemmons (1990) which estimates the cost of converting $\mathrm{DUF}_{6}$ to $\mathrm{DUF}_{4}$ to be $\$ 2 / \mathrm{kg} \mathrm{U}$ and the cost of converting 
$\mathrm{DUF}_{6}$ to $\mathrm{DU}_{3} \mathrm{O}_{8}$ to range from $\$ 3.30$ to $\$ 4.20 / \mathrm{kg} \mathrm{U}$. Thus, converting $\mathrm{DUF}_{6}$ to $\mathrm{DUF}_{4}$ is estimated to cost $50-60 \%$ of that for conversion to $\mathrm{U}_{3} \mathrm{O}_{8}$. The only other cost data available is a qualitative statement during the $\mathrm{DUF}_{6}$ Conversion Corporate Capability Briefings to DOE and contractor staff associated with the conversion procurement to the effect that the cost of converting $\mathrm{DUF}_{6}$ to $\mathrm{DUF}_{4}$ was "less than $80 \%$ " of the cost of conversion to $\mathrm{DU}_{3} \mathrm{O}_{8}$. Finally, an even more qualitative comparison of flowsheets for conversion of $\mathrm{DUF}_{6}$ to either $\mathrm{DUF}_{4}$ or $\mathrm{DU}_{3} \mathrm{O}_{8}$ shows that the facilities and steps required for conversion are essentially identical except that high-temperature steam oxidation of the $\mathrm{DUF}_{4}$ is not required if this is the conversion product. Thus, the cost of a DUF $_{4}$ product would be expected to be somewhat but not substantially less than the cost of a $\mathrm{DU}_{3} \mathrm{O}_{8}$ product form. Based on this information, the cost of converting DUF to $_{3} \mathrm{U}_{8}$ taken from Reid (1999) was multiplied by $50-80 \%$ to yield the range of costs for converting DUF $_{6}$ to $\mathrm{DUF}_{4}$.

Container, Transportation, and Disposal Costs. Transportation costs were based on shipments from the Paducah Gaseous Diffusion Plant to the NTS as described by Reid (1999). Costs for containers, transportation, and disposal were scaled from these estimates of container numbers using values derived by Reid (1999) for DU metal and $\mathrm{DU}_{3} \mathrm{O}_{8}$ according to the type of container selected for each DU form. Disposal costs were adjusted for recent increases from $\$ 7.50 / \mathrm{ft}^{3}$ $\left(\$ 250 / \mathrm{m}^{3}\right)$ to $\$ 9 / \mathrm{ft}^{3}\left(\$ 320 / \mathrm{m}^{3}\right)$. Costs for special packaging (e.g., encapsulation, liners) or treatment (e.g., grouting) were not considered by Reid (1999). Although further reduction of voids (e.g., by tailoring of container size/shape to the DU form) may be necessary to meet the NTSWAC, this may not significantly affect the numbers of containers needed because the amount of DU per container would remain the same. The numbers of containers, and thus the costs for containers, transportation, and disposal, could be increased significantly, however, if voids must be filled with inert material or if treatment of the DU forms is determined to be required.

Total Cost Estimate. Based on the above data and considerations, the estimated cost of converting 700,000 $\mathrm{MT}$ of $\mathrm{DUF}_{6}$ to each of the four product forms, packaging it in an appropriate container, transporting it to the NTS, and burying it in a near-surface disposal facility is given in Table 5 .

Analysis. While there are many remaining uncertainties in the cost estimates, the fact that the estimates have a common, consistent source means that the relationship among the costs should be less uncertain. Given current uncertainties in estimates of product volumes, bulk densities, etc., and the simplified nature of the life cycle cost estimates, further refinement of assumptions (e.g., about container types) and/or cost estimates does not appear warranted in advance of expected technical discussions and negotiations with staff at the NTS.

Despite the uncertainties, some broad conclusions and generalizations can be drawn. First, the total cost for the $\mathrm{UF}_{4}$ form is less than the cost of the cost of the others, the oxide forms are intermediate and comparable, and the cost of metal is the greatest. Second, conversion costs are typically much higher than the sum of all other costs (variation notwithstanding). For all forms, container costs are comparable with those for transportation to the disposal site, and these two cost categories are each significantly larger than the estimated disposal costs at the NTS. 
Table 5. Estimated costs for conversion, containers, transportation, and disposal of DU at the NTS

\begin{tabular}{lccccc}
\hline & \multicolumn{5}{c}{ Costs $(\$ \mathrm{M})$} \\
\cline { 2 - 6 } \multicolumn{1}{c}{ DU product form } & Conversion & Containers & Transportation & Disposal & Total \\
\hline DU metal & $2400^{a}$ & $59^{b}$ & $66^{b}$ & $12^{b}$ & 2500 \\
$\mathrm{DUF}_{4}$ & $460-740^{c}$ & $100-140$ & $99-130$ & $67-87$ & $730-1100$ \\
$\mathrm{DUO}_{2}$ & $1200^{d}$ & $90-120$ & $85-120$ & $49-75$ & $1400-1500$ \\
$\mathrm{DU}_{3} \mathrm{O}_{8}$ & 920 & $93-170$ & $88-160$ & $60-100$ & $1200-1350$ \\
\hline
\end{tabular}

${ }^{a}$ Based on the conventional two-step metallothermic reduction process (see Reid 1999). Optimistic assumptions about the potential for development and implementation of a lower-cost advanced conversion process are not warranted based on current information.

${ }^{b}$ Values are based on disposal using a container which allows compliance with the NTS weight limits. However, the NTS "action levels" for DU activity concentration are exceeded by about a factor of five for DU metal and significant void space is still present (see Table 4). Thus, disposal of DU metal could require an alternative package design that could change these costs.

${ }^{c}$ The cost of converting $\mathrm{DUF}_{6}$ to $\mathrm{UF}_{4}$ was estimated by using the a range of conversion costs given in Lemons et al. (1990) and a qualitative statement by a vendor to establish the a range of relative costs to convert DUF to $_{6}$ DUF $_{4}$ as compared with $\mathrm{DU}_{3} \mathrm{O}_{8}$ (i.e., $50-80 \%$ ). This range was then multiplied by the cost of converting $\mathrm{DUF}_{6}$ to $\mathrm{DU}_{3} \mathrm{O}_{8}$ taken from Reid (1999) to yield a range of costs to convert $\mathrm{DUF}_{6}$ to $\mathrm{DUF}_{4}$.

${ }^{d}$ Costs were estimated by taking the ratio of the conversion cost for $\mathrm{DUO}_{2}$ (ceramic pellets) to that for $\mathrm{DU}_{3} \mathrm{O}_{8}$ (1.29) given by in Elayat, Zoller, and Szytel (1997) times the conversion cost for $\mathrm{DU}_{3} \mathrm{O}_{8}$ shown in Column 2.

\subsection{SUMMARY}

All of the available information related to the disposal of DU at the NTS indicates that any waste form could be made acceptable for disposal. Each waste form has a different set of associated issues that would need to be addressed as part of the waste acceptance process at the NTS. The resolution of these issues could require a significant commitment of time and resources and could lead to additional costs for packaging and treatment of the $\mathrm{DUF}_{6}$ conversion product in order for the waste generator program and waste stream profile to be approved for disposal.

\section{GENERAL CONSIDERATIONS REGARDING DISPOSAL OF DU AT THE NTS}

This section discusses a number of issues concerning potential disposal of DU conversion products at the NTS.

\subsection{DOE AND NRC RESPONSIBILITIES REGARDING DISPOSAL OF DU GENERATED BY THE USEC}

Section 3109 of the USEC Privatization Act [P.L. 104-134, Title III, Chapter 1, Subchapter A (April 26, 1996); 42 U.S.C. 2297h-7] allocates liabilities arising out of the operation of uranium 
enrichment enterprises between the U.S. Government (including DOE) and USEC. According to section 3109(a), all liabilities arising out of uranium enrichment operations conducted before July 1, 1993, including disposal of DU generated before that date, are the responsibility of DOE. In addition, DOE is responsible for disposition of any DU generated by USEC between July 1, 1993, and the date of privatization (i.e., July 28, 1998). USEC is responsible for any liabilities arising out of its operations after the date of privatization.

Regarding disposal of any DU generated after the date of privatization, section 3113(a) of the USEC Privatization Act [42 U.S.C. 2297h-11(a)] provides that

- USEC (or any other person licensed by the NRC to operate a uranium enrichment facility) may request that DOE accept for disposal LLW, including $D U$ if it is ultimately determined to be LLW, generated by operations at the gaseous diffusion plants or as a result of treatment of such LLW at a location other than the gaseous diffusion plants.

- If USEC (or any other person licensed by the NRC to operate a uranium enrichment facility) asks DOE to dispose of LLW as described above, including DU, DOE must accept the LLW for disposal.

Under section 3113(a), USEC is not required to select DOE to dispose of its LLW. However, if USEC decides to ask DOE to dispose of LLW, including DU, DOE must accept the waste for reimbursement in an amount equal to DOE's costs, including a pro rata share of any capital costs, but in no event more than an amount equal to that which would be charged by commercial, state, regional, or interstate compact entities for disposal of the same waste.

In May 1998, DOE and USEC entered a memorandum of agreement (MOA) implementing section 3109(a) of the USEC Privatization Act. This MOA transfers ownership of 9186 cylinders of DUF ${ }_{6}$, which was the amount generated between July 1993 and July 1998, from USEC to DOE. The MOA does not obligate DOE to disposition this $\mathrm{DUF}_{6}$ in any particular way.

In June 1998, a second MOA was signed under which ownership of 2026 additional cylinders of DUF $_{6}$ will be transferred from USEC to DOE during government fiscal years 1999 through 2004. However, this MOA, which addresses DU generated by USEC after privatization, was not entered pursuant to section 3113(a) of the USEC Privatization Act. Instead, it was entered pursuant to sections 161v. [42 U.S.C. 2201(v)] and 1311 [42 U.S.C. 2297b-10] of the Atomic Energy Act of 1954 [P.L. 83-703], as amended, which provide that DOE may supply services in support of USEC. Like the May 1998 MOA, this MOA also does not obligate DOE to disposition the $\mathrm{DUF}_{6}$ in any particular way.

In the future, USEC may choose one or more of the following options for managing its DUF :

- Enter additional agreements with DOE like the June 1998 MOA, which transfer ownership of DUF $_{6}$ to DOE, and for a fee, allow DOE to disposition the transferred DU in accordance with DOE orders, regulations, and policies.

- Ask DOE to dispose of DU pursuant to section 3113(a) of the USEC Privatization Act. In this circumstance, USEC could either transfer ownership of the DUF $_{6}$ directly to DOE for treatment and disposal or contract with a third party to treat the $\mathrm{DUF}_{6}$ (e.g., convert it to another chemical form) before shipping it to DOE for disposal. In either case, DOE would 
be obligated by section 3113(a) of the USEC Privatization Act to accept and dispose of the DU at a DOE LLW disposal facility in accordance with DOE orders, regulations, and policies.

- Transfer ownership of DUF to $_{6}$ a third-party conversion facility that is authorized by an NRC license or a DOE contract to convert and transfer DU and/or other products of conversion for use or disposal by others. In such circumstances, the NRC license or DOE contract held by the conversion facility would govern any transfer of conversion products for use or disposal.

Nothing in the Atomic Energy Act, the USEC Privatization Act, or the National Energy Policy Act of 1992 [P.L. 102-486] authorizes NRC to regulate DOE LLW disposal facilities that receive DU for disposal at the request of USEC (or any other person licensed by the NRC to operate a uranium enrichment facility), even if a third-party conversion facility changes the chemical form of the DU before transferring the converted material to DOE.

\subsection{INSTITUTIONAL AND STAKEHOLDER ISSUES}

Currently, DOE self-regulates LLW disposal activities at the NTS. No other federal or state agencies have jurisdiction to issue permits or licenses applicable to LLW management at the NTS. Also, the areas where LLW management occurs are not subject to any federal facility compliance agreements or other enforceable instruments (e.g., compliance orders) that govern LLW management activities. However, there are stakeholder concerns about LLW management that need to be considered, along with the issues associated with meeting the NTSWAC.

Prominent stakeholder concerns that have a direct impact on LLW disposal at the NTS include the following:

- Opposition to transportation of LLW across Hoover Dam and through downtown Las Vegas.

- Ensuring funding of long-term stewardship of LLW disposal facilities at the NTS, where the mechanisms for funding such stewardship are not yet satisfactory.

- Equity issues related to the apparent designation of the NTS by DOE as one of two preferred LLW disposal sites.

- Opposition of the state of Nevada and its representatives to establishing a repository at the Yucca Mountain Site. In response to DOE's recently announced LLW disposal plans (Federal Register 1999), the governor of Nevada recently (Guinn 2000) sent Secretary Richardson a letter to the effect that DOE's insistence on going ahead with the repository project in the face of opposition from Nevada residents and politicians is jeopardizing the comparatively cooperative relationship Nevada and DOE have enjoyed on issues involving the NTS.

Some stakeholder issues are being addressed by the "Agreement-in-Principle Between the Department of Energy and the State of Nevada." The currently effective Agreement-in-Principle was voluntarily entered into between DOE/NV and the state of Nevada in June 1999. The agreement, which is not legally enforceable, contains a provision for a Low-Level Waste Oversight Program. The purpose of the oversight program is to give the state of Nevada the opportunity to identify DOE/NV activities that may adversely impact the public's health and safety or the environment. Under the Agreement-in-Principle, DOE/NV has agreed to provide resources to the state of Nevada to support certain activities related to implementation of their 
oversight role. These activities include emergency preparedness training and environmental monitoring. Regarding LLW, one provision of the agreement that could impact disposal of DU at the NTS allows Nevada to "review and comment on adequacy of waste generating organization determinations and documentation of what material meets the DOE definition of, and should be managed as, low-level waste." Currently, there is no on-site program at the NTS to quantitatively (e.g., through sampling and testing) verify on arrival that incoming wastes meet the NTSWAC, instead relying on generator certifications for verification. However, in response to this stakeholder concern, the NTS initiated development of an on-site waste verification program in 1999. Implementation of such a program could lead to requirements for inspecting the contents of some or all waste packages, which could have a significant impact on costs.

Finally, DOE/NV staff have noted that the sheer volume of the a DU waste stream could arouse stakeholder reactions.

These stakeholder issues could influence or delay the shipment of DU waste to the NTS but at this point are not considered to be significant limitations to the disposal of wastes, primarily because of Nevada's lack of jurisdiction.

\subsection{IMPACTS OF TRACE IMPURITIES ON DISPOSAL AT THE NTS}

Transuranic radionuclides such as ${ }^{238,239,}{ }^{240} \mathrm{Pu},{ }^{241,243} \mathrm{Am}$, and ${ }^{237} \mathrm{~Np}$ are potentially present in DUF $_{6}$ in trace quantities. Other radionuclides such as ${ }^{99} \mathrm{Tc}$ and ${ }^{230,232} \mathrm{Th}$ may also be present in DUF $_{6}$. These impurities are the result of the introduction of recycled uranium into the uranium enrichment cascade in the early 1960s. Other impurities include DU decay products. Available data describing the radionuclides and activity concentrations of trace impurities in $\mathrm{DUF}_{6}$ are limited, and a concerted effort is under way to characterize these impurities. Once additional data are developed that quantify the trace radionuclides in $\mathrm{DUF}_{6}$ materials, the consequences of these radionuclides on the DU conversion products and their subsequent disposal can be clearly established.

The impacts of any trace impurities in DU conversion products on disposal at the NTS is an issue to be resolved in the RWAP process. As part of the RWAP process, the waste generator program will be carefully reviewed, including the waste characteristics and the waste characterization methods (see Sect. 3.1). Additionally, the waste stream profile of the DUF $_{6}$ conversion product will be carefully reviewed. Trace radionuclides that are present in $\mathrm{DUF}_{6}$ conversion products will have to be reported under any of the following conditions:

- The activity concentration of a radionuclide in the final waste form exceeds $1 \%$ of the action limits in the NTSWAC. For these radionuclides, rigorous characterization is required.

- The radionuclide is ${ }^{241} \mathrm{Pu},{ }^{242} \mathrm{Cm}$, or is transuranic with a half-life greater than 5 years. The mass of the waste must be determined, and if the concentration exceeds $1 \mathrm{nCi} / \mathrm{g}$, rigorous characterization is required.

- The activity concentration of a radionuclide exceeds $1 \%$ of the total activity concentration of the final waste form. For radionuclides with concentrations less than the detection limit for accepted characterization methods, process knowledge can be used for characterization. 
Trace radionuclides that are required to be reported need to be characterized according to the waste characterization plan prepared as part of the RWAP process. Waste generators are encouraged to use innovative methods for waste characterization, and a graded approach to characterization is used by DOE/NV. As a result, the extent of reporting and characterization of trace radionuclides in $\mathrm{DUF}_{6}$ conversion products is an additional uncertainty that could affect the costs for disposal.

Based on process knowledge, the presence of trace impurities in $\mathrm{DUF}_{6}$ is not expected to be a technical issue affecting the acceptability of wastes for disposal at the NTS because the impurity concentrations are expected to be below concentrations that would call for additional actions and the conversion plant product can be readily characterized. However, the large volumes of $\mathrm{DUF}_{6}$ conversion product and the heightened concern of the public regarding the management of radioactive materials, especially materials with transuranic radionuclides, could become a national or local stakeholder issue for the $\mathrm{DUF}_{6}$ management program. Perception issues such as this need to be monitored carefully as part of implementation of the $\mathrm{DUF}_{6}$ management program.

\subsection{UTILITY OF DU FORMS FOR POTENTIAL BENEFICIAL USES}

The primary purpose of this paper is to assess the suitability of various DU conversion product forms for near-surface disposal and preferences in this regard to ensure that such a disposition path is available. However, beneficial use of DU conversion products may be desirable to reduce the overall cost to DOE for DU disposition or to provide improvements in DOE operations. The purpose of this section is to qualitatively assess the various forms of DU with respect to their utility for beneficial uses. The beneficial uses that could consume substantial quantities of DU require further development from both technical and institutional perspectives before they could be implemented, and a determination whether any of these uses are worthwhile has not been made.

$\underline{\mathrm{DUO}}_{2}$. Potential large-quantity uses of DU that appear to be the most promising are in the manufacturing of heavy concrete components (e.g., for dry spent-fuel storage silos) and as fill to eliminate void spaces inside of a repository package containing spent-fuel assemblies. For these applications, the high density that can be achieved with sintered $\mathrm{DUO}_{2}$ is a necessity. Consequently, this form has the highest utility for large-quantity beneficial uses. Depleted uranium dioxide may also be suitable for other beneficial uses (e.g., as a catalyst), but this is very speculative.

DU Metal. Depleted uranium metal has established beneficial uses ranging from radiation shielding to ordnance. However, the quantity of DU used for such purposes is presently a small fraction of the available inventory. Large-quantity use in spent-fuel shipping casks is possible, but DU metal is presently more expensive than the alternatives. Uranium metal has also been proposed for new applications which include use as an alloying constituent and as forklift counterweights, where its unique properties may offer advantages that offset its higher cost compared with alternatives. However, the use of DU metal as an alloying constituent is still speculative, and these new applications involve the presence of DU in unregulated areas where workers or the public will be exposed. Even if the new applications of DU are technically viable, the probability of using DU in unregulated areas is significantly diminished by the present 
institutional and regulatory environment that opposes recycle of metals that are volumetrically contaminated with radioactivity.

$\underline{D U}_{3} \underline{\mathrm{O}}_{8}$ and $\mathrm{DUF}_{4}$. Depleted $\mathrm{U}_{3} \mathrm{O}_{8}$ and $\mathrm{UF}_{4}$ are not directly useful forms of DU. Of the two, $\mathrm{DUF}_{4}$ has greater utility because of its flexibility: it can be converted more readily to any of the oxides or to the metal using existing processes. Depleted $\mathrm{U}_{3} \mathrm{O}_{8}$ is the least useful, because it cannot achieve the high density of $\mathrm{UO}_{2}$ and it is not a preferred feed material for producing either DU metal or $\mathrm{DUO}_{2}$.

\subsection{NATIONAL ENVIRONMENTAL POLICY ACT}

The DOE issued a final PEIS (DOE 1999a) and ROD (DOE 1999c) concerning alternative management strategies for the long-term management of $\mathrm{DUF}_{6}$. The ROD states:

DOE's preferred alternative for the long-term management and use of depleted $\mathrm{UF}_{6}$ is to begin conversion of the depleted $\mathrm{UF}_{6}$ inventory, as soon as possible, to depleted uranium oxide, depleted uranium metal, or a combination of both. The conversion products, such as fluorine, would be used as much as possible, and the remaining products would be stored for future uses or disposal. The Department currently expects that conversion to depleted uranium metal would be performed only if uses become available. At this time, the Department does not believe that long-term storage as depleted uranium metal and disposal as depleted uranium metal are reasonable alternatives; however, the Department remains open to exploring these options further.

The section of the ROD addressing alternatives dismissed from detailed consideration states:

Storage and Disposal as Depleted Uranium Metal. Conversion of depleted $\mathrm{UF}_{6}$ to depleted uranium metal for long-term storage and conversion to depleted uranium metal for disposal were not analyzed in depth as reasonable alternatives in the Final PEIS. These alternatives were rejected because of higher conversion cost for some processes used to convert $\mathrm{UF}_{6}$ to metal, the lower chemical stability of uranium metal as opposed to uranium oxide thus requiring different considerations for handling and storage, and uncertainty over the suitability of depleted uranium metal as a final disposal form. At this time, the Department does not believe that long-term storage as depleted uranium metal and disposal as depleted uranium metal are reasonable alternatives; however, the Department remains open to exploring these options further.

Storage and Disposal as Depleted Uranium Tetrafluoride $\left(U F_{4}\right)$. Long-term storage as depleted $\mathrm{UF}_{4}$ and disposal as depleted $\mathrm{UF}_{4}$ were also not analyzed in depth as reasonable alternatives in the Final PEIS. Although more stable than $\mathrm{UF}_{6}, \mathrm{UF}_{4}$ has no identified direct use, offers no obvious advantage in required storage space, and is less stable than oxide forms. Further, as a disposal form, $\mathrm{UF}_{4}$ is soluble in water.

The section of the ROD concerning comments on the final PEIS states:

One reviewer, BNFL Inc., reiterated their previous comments that DOE should have analyzed in depth, the environmental impacts of conversion of the depleted $\mathrm{UF}_{6}$ to 
depleted uranium metal for long-term storage and disposal. DOE addressed these comments in volume 3 of the Final PEIS and earlier in this ROD. At this time, the Department does not believe that long-term storage as depleted uranium metal and disposal as depleted uranium metal are reasonable alternatives; however, the Department remains open to exploring these options further. Should the Department be persuaded that it is reasonable to convert the depleted $\mathrm{UF}_{6}$ to depleted uranium metal for long-term storage or disposal, these alternatives would be analyzed in detail in future NEPA reviews, as necessary.

The decision summarized in the preceding quoted material indicates that additional programmatic and/or site-specific National Environmental Policy Act (NEPA) actions may be required if $\mathrm{DUF}_{4}$ were to be the conversion product or disposal form or if DU metal were to be the disposal form.

Beyond the above consideration, which is specific to $\mathrm{DUF}_{4}$ and DU metal, an important factor in the selection of the preferred alternative in the ROD is the focus on prompt conversion, beneficial uses, and long-term storage of DU. As a consequence, disposal issues for any form of DU may have to be addressed in subsequent NEPA actions. This view seems to be supported by the following portion of the ROD:

The cumulative impacts of conversion, long-term storage, and disposal activities could not be determined because specific sites and technologies have not been designated for these options. Further analyses of cumulative impacts would be performed as required by NEPA regulations for any technology or siting proposals that would involve these facilities.

The additional NEPA actions are not expected to delay the request for proposal for the conversion of $\mathrm{DUF}_{6}$. Conceptual design of a facility for $\mathrm{DUF}_{6}$ conversion and preliminary studies for selecting the appropriate technology should be allowable without any additional requirements for compliance with NEPA. However, any supplement or revision to the programmatic EIS and ROD would need to start quickly and proceed in parallel with preparation of the site-specific EIS that is a necessary precursor to the conversion and disposition of DUF 6 . The site-specific EIS, as well as any changes to the PEIS and the ROD, would need to be completed prior to initiating construction of the conversion plant. 


\section{REFERENCES}

Biwer, B. M., et al. 2000. "Depleted uranium disposal feasibility assessment," Appendix D in Hightower, J. R., and J. R. Trabalka, Depleted Uranium Storage and Disposal Trade Study Summary Report, ORNL/TM-2000/10, January 2000.

DOE (U.S. Department of Energy) 1999a. Programmatic Environmental Impact Statement for Alternative Strategies for the Long-Term Management and Use of Depleted Uranium Hexafluoride, DOE/EIS-029, Washington, D.C., April 1999.

DOE (U.S. Department of Energy) 1999b. "Commercial Disposal Policy Analysis for LowLevel and Mixed Low-Level Wastes," Office of Environmental Management, March 9, 1999.

DOE (U.S. Department of Energy) 1999c. "Record of Decision for Long-Term Management and Use of Depleted Uranium Hexafluoride," 64 FR 43358-43364, August 10, 1999.

DOE/NV (U.S. Department of Energy, Nevada Operations Office) 1999. "Nevada Test Site Waste Acceptance Criteria," DOE/NV-325, NTSWAC, Rev. 2, Waste Management Division.

Dubrin, J. W., et al. 1997. The Engineering Analysis Report for the Long-Term Management of Depleted Uranium Hexafluoride, UCRL-AR-124080, Vol. 1, Rev. 2, May 1997.

Duerksen, W. K., et al. 2000. "Selection of optimum storage forms for depleted uranium," Appendix B in Hightower, J. R., and J. R. Trabalka, Depleted Uranium Storage and Disposal Trade Study Summary Report, ORNL/TM-2000/10, January 2000.

Elayat, H., Zoller, J., and Szytel, L. 1997. Cost Analysis Report for the Long-Term Management of Depleted Uranium Hexafluoride, Lawrence Livermore National Laboratory, Livermore, Calif., UCRL-AR-127650, May 1997.

Epstein, M., Luangdilok, W., Plys, M. G., and Fauske, H. K. 1996. "On Prediction of the Ignition Potential of Uranium Metal and Hydride," Nuclear Safety 37(1) January-March 1996.

Federal Register 1999. "Identification of Preferred Alternatives for the Department of Energy's Waste Management Program: Low-Level Waste and Mixed Low-Level Waste Disposal Sites," 64 FR 69241-69242, December 10, 1999.

Guinn, K. 2000. Letter from Kenny Guinn (Governor of Nevada) to Bill Richardson (Secretary of Energy) regarding designation of the NTS as a regional facility for the disposal of lowlevel radioactive and mixed waste from DOE's nuclear facilities, January 10, 2000.

Katz, J. J., G. T. Seaborg, and L. R. Morss 1986. The Chemistry of the Actinide Elements, Vol. 2, Second Edition, Chapman and Hall, New York, 1986. 
Kozak, M. W., Feeney, T. A., Leigh, C. D., and Stockman, H. W.1992. Performance Assessment of the Proposed Disposal of Depleted Uranium as Class A Low-Level Waste, Letter Report submitted to F. W. Ross, U.S. Nuclear Regulatory Commission, December 16, 1992.

Lemons, T. R., et al. 1990. The Ultimate Disposition of Depleted Uranium, K/ETO-44, December 1990.

NRC (U.S. Nuclear Regulatory Commission) 1992. Letter from J. W. N. Hickey, NRC, to W. H. Arnold, Louisiana Energy Services L.P. on depleted uranium disposition, September 22, 1992.

NRC (U.S. Nuclear Regulatory Commission) 1994. "Final Environmental Impact Statement for the Construction and Operation of Claiborne Enrichment Center, Homer, Louisiana," Docket No, 70-3070, NUREG-1484, Vol. 1 and 2, Office of Nuclear Material Safety and Safeguards, Washington, D.C.

NRC (U.S. Nuclear Regulatory Commission) 1995. Letter from NRC (R. Bernero) to DOE (C. Bradley, Jr.), January 3, 1995.

NRC 1999. "Order to Exempt Envirocare of Utah, Inc. from Certain NRC Licensing Requirements for Special Nuclear Material,” Docket No. 40-8989, 64 FR 27826-27828. May $21,1999$.

Reid, R. L. 2000. "Simplified life cycle costs for selected DUF $_{6}$ conversion and management options," Appendix A in Hightower, J. R., and J. R. Trabalka, Depleted Uranium Storage and Disposal Trade Study Summary Report, ORNL/TM-2000/10, January 2000.

Sattler, J. 2000. U.S. DOE, Ohio Field Office, personal communication to J. R. Hightower, February 2000.

Sink, C. 1999. "Non-HEU Uranium Trade Study: Results and Path Forward," presentation material, August 1999.

Thomas, D. 1999. Former manager responsible for waste management at Fernald, personal communication to J. R. Hightower, October 1999. 
ORNL/TM-2000/161

\section{INTERNAL DISTRIBUTION}

$\begin{aligned} 2 . & \text { J. M. Begovich } \\ 3 . & \text { J. B. Clendenen } \\ 3-4 . & \text { A. G. Croff } \\ 5 . & \text { L. R. Dole } \\ 6 . & \text { J. J. Ferrada } \\ 7-11 . & \text { J. R. Hightower, Jr. } \\ 12 . & \text { G. T. Mays } \\ 13 . & \text { G. E. Michaels }\end{aligned}$

\author{
14-15. D. W. Lee \\ 16. D. G. O'Connor \\ 17. R. L. Reid \\ 18. J. R. Trabalka \\ 19. K. A. Williams \\ 20. Central Research Library \\ 21. ORNL Laboratory Records-RC \\ 22. ORNL Laboratory Records-OSTI
}

\section{EXTERNAL DISTRIBUTION}

23. G. W. Benedict, DOE, Oak Ridge Operations Office, 200 Administration Road, Oak Ridge, TN 37831

24. N. P. Buschman, U.S. Department of Energy, Office of Depleted Uranium Hexafluoride, NE-30, Room E-469, 19901 Germantown Road, Germantown, MD 20874-1290

25. J. R. Gasper, Environmental Assessment Division, Argonne National Laboratory, Suite 6000, 955 L'Enfant Plaza S.W., Washington, DC 20024

26. R. M. Knipp, U.S. Department of Energy, Immediate Office of the Director, NE-1, Room 5A-157, 1000 Independence Avenue, S.W., Washington, DC 20585

27. M. J. Letourneau, EM-22, Room 1099, Cloverleaf Building, 19901 Germantown Road, Germantown, MD 20874

28. S. R. Martin, DOE, Oak Ridge Operations, P.O. Box 2008, Oak Ridge, TN 37831-6269

29-30. N. L. Ranek, Environmental Assessment Division, Argonne National Laboratory, Suite 6000, 955 L'Enfant Plaza S.W., Washington, DC 20024

31. Robert R. Price, U.S. Department of Energy, NE-20, Room E-461, 19901 Germantown Road, Germantown, MD 20874-1290

32-36. K. M. Shaw, U.S. Department of Energy, Office of Depleted Uranium Hexafluoride, NE30, Room E-475, 19901 Germantown Road, Germantown, MD 20874-1290

37. P. I. Stumbo, DOE, Oak Ridge Operations Office, 200 Administration Road, Oak Ridge, TN 37831

38. M. A. Reeves, DOE, Oak Ridge Operations Office, 200 Administration Road, Oak Ridge, TN 37831

39. J. E. Rhoderick, EM-22, Room 1183, Cloverleaf Building, 19901 Germantown Road, Germantown, MD 20874

40. R. W. Rucker, DOE, Oak Ridge Operations Office, 200 Administration Road, Oak Ridge, TN 37831

41-45. A. F. Tavares, U.S. Department of Energy, Office of Depleted Uranium Hexafluoride, NE30, Room 1I-062, 1000 Independence Avenue, S.W., Washington, DC 20585

46. M. S. Taylor, Bechtel Jacobs Company LLC, P. O. Box 2003, MS-7239, Oak Ridge, TN 37831-7239. 
47. D. W. Toukay, EM-22, Room 1206, Cloverleaf Building, 19901 Germantown Road, Germantown, MD 20874

48. D. K. Wierville, DOE, Oak Ridge Operations Office, Room G 126-3, Federal Office Building, 200 Administration Road, Oak Ridge, TN 37831 